\title{
Component of Trust for Developing Crowdwork System: A Systematic Literature Review
}

\author{
Sugiarto Hartono ${ }^{*}, 1,2$, Meyliana ${ }^{1,2}$, Ahmad Nizar Hidayanto ${ }^{1,3}$, Harjanto Prabowo ${ }^{1}$ \\ ${ }^{1}$ Computer Science Department, Bina Nusantara University, 11480, Indonesia \\ ${ }^{2}$ Information Systems Department, School of Information Systems, Bina Nusantara University, 11480, Indonesia \\ ${ }^{3}$ Faculty of Computer Science Universitas Indonesia, 16424, Indonesia
}

\begin{tabular}{l} 
A R T I C L E I N F O \\
\hline Article history: \\
Received: 09 July, 2020 \\
Accepted: 07 August, 2020 \\
Online: 17 September, 2020
\end{tabular}

Keywords:
Component
Trust
Crowdwork System

\section{Introduction}

Crowdwork system is a portal that allows employers to find workers on a project-based online basis. Crowdworking is a sociotechnical work system formed through a series of relationships that connect organizations, individuals, technology and work activities. Online crowdwork takes place in the online marketplace which allows companies to find workers and supports workers in finding work [1]. Through online crowdwork, workers will carry out performance activities through distributed crowdworkers and be financially funded by job providers (can be individuals, groups, or organizations). Crowdworking uses internet technology to answer the needs of the workforce digitally [2]. Crowdworking initially emerged using well-known concepts such as sharing economy and collaborative consumption. Crowdworking is an option to hire labor.

Freelancing is greatly helped by the crowdworking platform system. Crowdworking is growing nowadays and starting to be glimpsed by workers. Crowdworking can provide opportunities to be able to work flexibly through digital platforms. A survey shows

*Corresponding Author: Sugiarto Hartono, shartono@binus.edu that there are almost five million crowdworker workers in the UK [3]. $18 \%$ of Netherlands citizen have tried to find work through platforms digital [4]. Around $12 \%$ of the Swedish population work as gig workers [5]. According to Indonesian Central Statistics Agency (BPS) at the end of 2018, as many as 56.8\% of Indonesians worked in the informal sector, which is accompanied by an increase in the number of workers who are entrepreneurs in Indonesia, including freelancers. In May 2019, there are 129.36 million workforces in Indonesia. Freelance took $4.55 \%$ or around 5.89 million people. This number increased 16\% from 2018 (data is gained from Sribulancer, one of the Freelance Indonesia service providers). This increase is due to the fact that crowdworking facilitates connectivity in the global workforce search network and enables rapid scalability [6]. From the employer side, crowdworking can also change fixed costs into variable costs for employee cost.

Trust often linked to the someone reputation in a system. User reputation is the only method to identify trust. There are various perspectives to estimate trust. Trust is one kind of sciences widely explored in computer science. Trust value can be measured through subjective opinion, whereas trust assessment can be 
calculated by combining user reputation with estimates from various sources [7]. Trust is also needed in the online labor system, such as crowdwork system.

The main problem related to trust in crowdwork system lies in the assessment of crowdworkers who are unfair, and the lack of transparency in the assessment given by the employer. This has an impact on job satisfaction and the continuous intention to participate in the crowdwork system. This is supported by Ye \& Kankanhalli's research [8] which says that trust is an important factor in the participation of workers in a crowdwork system. Feller et al. [9] also said that trust is one of the critical factors in the success of crowdworking and it has an impact on worker participation. In an online environment, trust can encourage participation and can mediate the relationship between environmental conditions and subsequent participation [10,11]. Therefore, this research will identify component factor of trust for developing crowdwork systems especially online freelancing platforms using systematic literature review.

\section{Theoretical Foundation}

\subsection{Crowdwork System}

According to Howcroft and Kåreborn [12], crowdwork has 4 (four) typologies that are intended to answer future issue and challenge. It also help to understand the complex field of crowdwork. The purpose of typology is to reduce the complexity of various kinds of crowdwork.

1. Online task

Online task crowdwork provide paid work (as the worker interest) for a specific task. Actors who initiate processes of this type are employers. The tasks are modular, ranging from micro work to more complex work.

2. Playbour

'Playbour' (a combination of work and games) is based on unpaid work. 'Playbour' [13] is an ideological strategy that connects games, labor creativity, and autonomy [14]. This type of crowdwork is according to workers request. Workers have more sense to innovate. It also increase workers productivity, because there is no clear boundaries between work and pleasure.

3. Asset-Based services

This type is a type of crowdwork that involves asset-based employment services. This category is closely related to the idea of sharing economy [15]. The tasks managed digitally, are mostly carried out offline and depend on the use of workers' assets.

4. Profession-based freelance

This type is for professional-based freelance jobs. This type of crowdwork tends to have a more attention that needs high level skills and knowledge.

According to Kuek et al. [16], crowdwork can be divided into 2 types (microwork and online freelancing) which has diffentiation in terms of size and complexity of the work. Kuek et al. explains, microwork refers to simple work and no need more time to accomplish. The worker doesn't need special skills. Online freelancing needs high level skills and experience in big projects. It also needs more time to complete task in online freelancing. The example of microwork is logo design, while the example of online freelancing is system development project. More than $50 \%$ of online freelancers is bachelor's degree, while $33 \%$ of workers in microwork have them.

\subsection{Trust}

Trust is a major problem in the dynamics of group organizations, for example political and social organizations [17]. Trust is defined as an attribute carried out by people about the motives of group authority. If people have confidence in the authority of the group, it proves that the person cares about their needs. This authority group has genuine interests, cares about the person's way of thinking and point of view, and considers each person's opinion, and acts fairly to the person. Trust reflects the assessment that the motives of the authority are full of kindness and care. Groups that have authority are motivated to act in a way that considers the well-being of people in the group [18].

Dwyer and Oh [19] state that trust is the desire to achieve longterm goals. The biggest failure in building relationships between sellers and consumers is a lack of trust. There are two main topics of trust

a. Trust in partner's honesty, related to trust in the honesty of partners / companies

b. Trust in partner's benevolence, related to trust in the company's good intentions

\section{Methodology}

This research uses a systematic literature review method by analyzing research paper or literature related to component factor of trust to develop crowdwork system. The phases of this research are divided into several stages, such as: determining the source of research literature, determining the pattern of literature search keywords, determining the inclusion and exclusion criteria, extracting data, and analyzing findings to answer the research problem formulation.

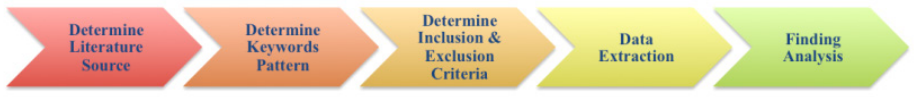

Figure 1: Phases of Systematic Literature Review

Source: Adapted from Tranfield and Smart [20]

A. Determine Source of Research Literature

In this initial stage, the research literature source will be determined to find research articles related to the topic. Research Literature Sources used include:

a. SAGE

b. Science Direct

c. ACM Digital Library

d. Springer

Keywords to search for research article papers use the Boolean operator in order to obtain the appropriate search results. Boolean operators used are OR and AND. The keywords used are:

a. Trust AND (component OR Attribute) AND (framework OR model) AND (crowdwork OR crowdsource OR (crowdwork AND system) OR (crowdsource AND system))

b. Trust AND (component OR Attribute) AND (framework OR model) AND (crowdwork OR crowdsource) 
The inclusion criteria for searching research articles consist of three stages. The first stage is the "Studies Found" process. Search results according to keywords will be categorized as "Studies Found". The next stage is "Candidate Studies". If the title and abstract of the research article in studies are found match to the research topic, then it is categorized as "Candidate Studies". The final stage of this research is "Selected Studies". If the paper on "Candidate Studies" answers the research problem statement, it will be included in "Selected Studies".

Exclusion criteria used in this study include:

a. The research article paper used in this study has a publication year for the past five years.

b. Research Paper has a complete writing structure, complete paper identities, and complete identity of the author.

c. If duplication occurs, it will be excluded in this literature study.

B. Data Extraction

This study analyzed 622 papers included in the Founded Studies and derived from 4 sources of literature and in accordance with the inclusion and exclusion criteria that have been set. Paper included in the Founded Studies is then re-analyzed the suitability between the title, abstract, and the research question, so that obtained 35 papers included in Candidate Studies. The paper included in Candidate Studies was then re-analyzed by reading the entire paper content and found 8 papers included in Selected Studies. Here are the findings of the literature from various sources:

Table 1: Result of Data Extraction

\begin{tabular}{|l|r|r|r|}
\hline \multicolumn{1}{|c|}{ Source } & Found Candidate Selected \\
\hline Sage & 51 & 8 & 3 \\
\hline Science Direct & 392 & 15 & 3 \\
\hline Springer & 7 & 2 & 1 \\
\hline ACM Digital Library & 172 & 10 & 1 \\
\hline Total & 622 & 35 & 8 \\
\hline
\end{tabular}

\section{Results and Discussion}

This study aims to discover what components factors of trust that are needed to develop the Crowdwork System. This section will present demographic data and characteristic trends from the literature included in the Selected Studies category, such as publication sources, publication years, classification of trust component of crowdwork or crowdsource system components of the literature study. The following table shows the sources of journal publications consist of title, year, and type of publication. There are 7 journal papers used in this literature review. It can be concluded that crowdworking is more closely researched in the disciplines of strategic information systems and management.

There are 16 authors who have written 7 papers in total. The 16 authors are grouped into 8 departments. Authors who contribute research on trust component of crowdworking or crowdsourcing tend to write with research approaches. Most of them have academic background $(87.5 \%, 14$ authors) and 2 authors $(12.5 \%)$ have industry background. The detailed of author name can be seen in table 3 .

Table 2: Source of Literature and Paper Discipline

\begin{tabular}{|c|c|c|c|c|c|}
\hline No & Title & $\begin{array}{c}\text { Paper } \\
\text { Discipline }\end{array}$ & Source & Year & Type \\
\hline 1 & $\begin{array}{l}\text { Crowdsourc } \\
\text { ing-Based } \\
\text { Business } \\
\text { Models [21] }\end{array}$ & Management & Sage & 2015 & Journal \\
\hline 2 & $\begin{array}{l}\text { Combining } \\
\text { User } \\
\text { Reputation } \\
{[22]}\end{array}$ & $\begin{array}{l}\text { Data and } \\
\text { Information } \\
\text { Quality }\end{array}$ & $\mathrm{ACM}$ & 2016 & Journal \\
\hline 3 & $\begin{array}{l}\text { Community } \\
\text { building on } \\
\text { crowdwork } \\
{[23]}\end{array}$ & $\begin{array}{l}\text { Political } \\
\text { Economy }\end{array}$ & Sage & 2020 & Journal \\
\hline 4 & \begin{tabular}{|l|} 
The Future \\
of Work: \\
New Roles \\
{$[24]$}
\end{tabular} & $\begin{array}{l}\text { Human } \\
\text { Resources }\end{array}$ & Sage & 2018 & Journal \\
\hline 5 & $\begin{array}{l}\text { Developing } \\
\text { and } \\
\text { maintaining } \\
\text { clients' } \\
\text { trust [25] }\end{array}$ & $\begin{array}{l}\text { Strategic } \\
\text { Information } \\
\text { Systems }\end{array}$ & $\begin{array}{l}\text { Science } \\
\text { Direct }\end{array}$ & 2018 & Journal \\
\hline 6 & \begin{tabular}{|l|} 
Should You \\
Really \\
Produce \\
{$[26]$}
\end{tabular} & $\begin{array}{l}\text { Product } \\
\text { Innovation } \\
\text { Management }\end{array}$ & Springer & 2017 & Journal \\
\hline 7 & \begin{tabular}{|l|} 
Solvers' \\
participatio \\
n [27]
\end{tabular} & $\begin{array}{l}\text { Strategic } \\
\text { Information } \\
\text { Systems }\end{array}$ & $\begin{array}{l}\text { Science } \\
\text { Direct }\end{array}$ & 2017 & Journal \\
\hline
\end{tabular}

Table 3: Author's Information

\begin{tabular}{|l|l|l|l|}
\hline \multicolumn{1}{|c|}{ Author } & Department & $\begin{array}{c}\text { Author's } \\
\text { Background }\end{array}$ & $\begin{array}{l}\text { \# of Author's } \\
\text { Publication }\end{array}$ \\
\hline $\begin{array}{l}\text { Andreas } \\
\text { Herrmann }\end{array}$ & $\begin{array}{l}\text { Business } \\
\text { Administratio } \\
\text { n, Law and } \\
\text { Economics }\end{array}$ & Academic & 1 \\
\hline $\begin{array}{l}\text { Archana } \\
\text { Nottamkandath }\end{array}$ & $\begin{array}{l}\text { Computer } \\
\text { Science }\end{array}$ & Academic & \\
\hline $\begin{array}{l}\text { Atreyi } \\
\text { Kankanhalli }\end{array}$ & $\begin{array}{l}\text { Computer } \\
\text { Science }\end{array}$ & Academic & 1 \\
\hline Christine Gerber & $\begin{array}{l}\text { Computer } \\
\text { Science }\end{array}$ & Academic & 1 \\
\hline
\end{tabular}




\begin{tabular}{|c|c|c|c|}
\hline Author & Department & $\begin{array}{c}\text { Author's } \\
\text { Background }\end{array}$ & $\begin{array}{l}\text { \# of Author's } \\
\text { Publication }\end{array}$ \\
\hline Davide Ceolin & $\begin{array}{l}\text { Computer } \\
\text { Science }\end{array}$ & Academic & 1 \\
\hline $\begin{array}{l}\text { Hua (Jonathan) } \\
\text { Ye }\end{array}$ & $\begin{array}{l}\text { Computer } \\
\text { Science }\end{array}$ & Academic & 1 \\
\hline Ji-Ye Mao & $\begin{array}{l}\text { Management } \\
\text { Science \& } \\
\text { Engineering }\end{array}$ & Academic & 1 \\
\hline Kevin Freitas & $\begin{array}{l}\text { Human } \\
\text { Resources }\end{array}$ & Industry & 1 \\
\hline Paul Groth & $\begin{array}{l}\text { Computer } \\
\text { Science }\end{array}$ & Academic & 1 \\
\hline Reto Hofstetter & $\begin{array}{l}\text { Marketing and } \\
\text { Communicati } \\
\text { on } \\
\text { Management }\end{array}$ & Academic & 1 \\
\hline $\begin{array}{l}\text { Suleiman } \\
\text { Aryobsei }\end{array}$ & $\begin{array}{l}\text { Management } \\
\text { Business }\end{array}$ & Industry & 1 \\
\hline Thomas Kohler & $\begin{array}{l}\text { Law and } \\
\text { Philosophy } \\
\text { (Open } \\
\text { Innovation \& } \\
\text { Crowdsourcin } \\
\text { g) }\end{array}$ & Academic & 1 \\
\hline $\begin{array}{l}\text { Valentina } \\
\text { Maccatrozzo }\end{array}$ & $\begin{array}{l}\text { Computer } \\
\text { Science }\end{array}$ & Academic & 1 \\
\hline Wan Fokkink & $\begin{array}{l}\text { Computer } \\
\text { Science }\end{array}$ & Academic & 1 \\
\hline $\begin{array}{l}\text { Wenyu (Derek) } \\
\text { Du }\end{array}$ & $\begin{array}{l}\text { Information } \\
\text { Systems }\end{array}$ & Academic & 1 \\
\hline
\end{tabular}

\begin{tabular}{|l|c|c|}
\hline \multicolumn{1}{|c|}{ Institutions } & \# of papers & $\%$ \\
\hline $\begin{array}{l}\text { Berlin Social Science } \\
\text { Center }\end{array}$ & 1 & 6.25 \\
\hline $\begin{array}{l}\text { Boston College Law } \\
\text { School }\end{array}$ & 1 & 6.25 \\
\hline Dream11 & 1 & 6.25 \\
\hline Elsevier B.V. & 1 & 6.25 \\
\hline $\begin{array}{l}\text { National University of } \\
\text { Singapore }\end{array}$ & 1 & 6.25 \\
\hline $\begin{array}{l}\text { Netherlands eScience } \\
\text { Center }\end{array}$ & 1 & 6.25 \\
\hline $\begin{array}{l}\text { Renmin University of } \\
\text { China, Beijing, China }\end{array}$ & 1 & 6.25 \\
\hline $\begin{array}{l}\text { The University of } \\
\text { Auckland }\end{array}$ & 1 & 25 \\
\hline $\begin{array}{l}\text { Universita della Svizzera } \\
\text { italiana }\end{array}$ & 1 & 6.25 \\
\hline Universities of St. Gallen & 1 & 1 \\
\hline VU University Amsterdam & 1 & (1 \\
\hline
\end{tabular}

Trust on crowdworking has been widely discussed over the past five years $(2015,2016,2017,2018,2019$, and 2020). There are 2 papers published on 2017, 2 papers published on 2018, 1 paper published on 2015, 1 paper published on 2016, 1 paper published on 2020.

According to 8 papers found in Selected Studies, there are 11 components and 38 indicators related to trust model on crowdwork platform. Reciprocal voting is described by project participation, project submitted, social ties, votes provided, votes received, worker's participation, worker's solution, and project duration. Open communication is described by community building, level of interaction, topics of interaction, purposes of interaction. Online testimonial is described by vividness, emotional absorption, and message-value congruency. Monetary reward is described by return of submission, submission, and financially rewarded. Cognitive effort is described by difficulty of understanding requirement, effort into understanding requirement, time and effort of task solving, time needed to solve problem. Loss of knowledge power is described by unique value, power base, respect to others, and unique knowledge. Initiating trust is described by escrow services, feedback system, and accreditation system. Augmenting trust is described by requirement analysis services and contract formation services. 
Maintaining trust is described by periodical evaluation and harmonious conflict resolution. User reputation is described by author reputation and stereotype reputation. Trustworthiness reputation is described by evidence prior performance, stereotype reputation, and user reputation. The details of indicator for each component can be seen on table 5 .

Table 5: Component, Definition, and Indicator of Crowdwork Systems

\begin{tabular}{|c|c|c|}
\hline Component & Definition & Indicator \\
\hline \multirow[t]{8}{*}{$\begin{array}{l}\text { Reciprocal } \\
\text { Voting }\end{array}$} & \multirow{8}{*}{$\begin{array}{l}\text { Based on cooperation and social influence theory, peer voting to competitive online } \\
\text { environment (such as crowdwork/crowdsource system) may trigger cooperation among } \\
\text { stakeholders through reciprocal voting. Cooperation may happen in competitions if there are } \\
\text { two persons who meet and interact repeatedly }[28,29] \text {. Reciprocity is a kind of cooperation in } \\
\text { competition [30,31]. The objective of reciprocal voting used to vote ideas/solution in online } \\
\text { system is to prevent social bias. The company can ignore that motive and allow vote to affect } \\
\text { innovation process [32,33]. The better the result of screening innovation process, the more } \\
\text { successful will get in innovation process }[34,35,36] \text {. So, the conception and knowledge for } \\
\text { social bias in online system (such as crowdwork or crowdsource system) is very critical for } \\
\text { open innovation. }\end{array}$} & \begin{tabular}{|l} 
Project \\
Participation
\end{tabular} \\
\hline & & Project Submitted \\
\hline & & Social Ties \\
\hline & & Votes Provided \\
\hline & & Votes Received \\
\hline & & $\begin{array}{l}\text { Worker's } \\
\text { Participation }\end{array}$ \\
\hline & & Worker's Solution \\
\hline & & Project Duration \\
\hline \multirow[t]{4}{*}{$\begin{array}{l}\text { Open } \\
\text { Communication }\end{array}$} & \multirow{4}{*}{$\begin{array}{l}\text { Management should provide open communication to make interaction decentralized. But, it } \\
\text { will impact to critical comments. Management may choose to take preventive action (such as } \\
\text { control to irresponsible autonomy). The persuasive effect of testimonials is based on heuristic } \\
\text { thinking and cognitive shortcuts (availability and representative heuristics). }[37,38]\end{array}$} & \begin{tabular}{|l|} 
Community \\
Building \\
\end{tabular} \\
\hline & & Level of Interaction \\
\hline & & $\begin{array}{l}\text { Topics } \\
\text { Interaction } \\
\end{array}$ \\
\hline & & $\begin{array}{l}\text { Purposes } \\
\text { Interaction }\end{array}$ \\
\hline \multirow{3}{*}{$\begin{array}{l}\text { Online } \\
\text { Testimonial }\end{array}$} & \multirow{3}{*}{$\begin{array}{l}\text { Testimonial includes description of personal experience or opinion. Some studies found that } \\
\text { testimonials are more persuasive than factual information, but other studies found conversely. } \\
\text { Testimonials are very efficient in public media because individual don't engage in extensive } \\
\text { cognitive processing of media messages. }[39,40,41,42]\end{array}$} & Vividness \\
\hline & & \begin{tabular}{|l|} 
Emotional \\
Absorption
\end{tabular} \\
\hline & & $\begin{array}{l}\text { Message-value } \\
\text { congruency }\end{array}$ \\
\hline \multirow[t]{3}{*}{ Monetary Reward } & \multirow{3}{*}{$\begin{array}{l}\text { Monetary reward includes on extrinsic motivation. It is provided as an incentive for } \\
\text { crowdworker [43]. Crowdworker can expect reward for solution they give to job provider [44]. } \\
\text { Monetary reward is the important factor for crowdworker to undertake the action in } \\
\text { crowdwork system [45,46]. Terwiesch and Xu did research on TaskCNPlatform [47]. They } \\
\text { suggest that monetary reward will stimulate participation of crowdworker on platform. Based } \\
\text { on social exchange theory, expectation of monetary reward should motivate crowdworker to } \\
\text { choose to act }[48,49,50] \text {. }\end{array}$} & \begin{tabular}{|l|} 
Return \\
Submission \\
\end{tabular} \\
\hline & & Submission \\
\hline & & $\begin{array}{l}\text { Financially } \\
\text { Rewarded }\end{array}$ \\
\hline \multirow[t]{4}{*}{ Cognitive Effort } & \multirow{4}{*}{$\begin{array}{l}\text { Cognitive effort is mandatory for problem solving on crowdworking platform. Cognitive effort } \\
\text { will take part as a medium for solving the gap between past solution/knowledge and current } \\
\text { problem. It's costly and will connect the expertise to the problem and develop solution for that } \\
\text { problem. Crowdworker must leverage cognitive effort to identify, understand the } \\
\text { requirement/problem, and propose the solution [51]. Crowdworkers are not likely to } \\
\text { participate when they perceive high cognitive effort is needed for that participation. } \\
\text { Crowdworkers expect the crowdwork platform can reduce cognitive effort, so it can build } \\
\text { crowdworker's trust to platform. For example, platform must give feedback to the } \\
\text { crowdworker if their solutions are not adapted [52,53]. By providing past solution, cognition } \\
\text { effort will be reduced [54,55]. }\end{array}$} & $\begin{array}{|ll|}\text { Difficulty of } \\
\text { Understanding } \\
\text { Requirement }\end{array}$ \\
\hline & & \begin{tabular}{|l|} 
Effort Into \\
Understanding \\
Requirement
\end{tabular} \\
\hline & & $\begin{array}{l}\text { Time and Effort of } \\
\text { Task Solving } \\
\end{array}$ \\
\hline & & $\begin{array}{l}\text { Time Needed to } \\
\text { Solve Problem }\end{array}$ \\
\hline
\end{tabular}




\begin{tabular}{|c|c|c|}
\hline Com & Definition & Indicator \\
\hline \multirow{4}{*}{$\begin{array}{l}\text { Loss } \\
\text { Knowledge } \\
\text { Power }\end{array}$} & \multirow{4}{*}{$\begin{array}{l}\text { Loss of knowledge power is a barrier to knowledge sharing. In crowdwork platform, } \\
\text { knowledge is a source of power by crowdworkers. Crowdworker have fear feeling when the } \\
\text { job provider know their ideas or solution before they have rewarded. Job provider act } \\
\text { opportunistically and not pay the crowdworker once they get the solution. It will impact trust } \\
\text { crowdworkers on job provider and they are not participating in crowdwork platform [56]. } \\
\text { Crowdworkers also may have feeling that crowdwork platform will misuse their solution and } \\
\text { it also impact to crowdworker's trust to platform [57,58]. }\end{array}$} & Unique Value \\
\hline & & Power Base \\
\hline & & Respect to Others \\
\hline & & Unique Knowledg \\
\hline \multirow[t]{3}{*}{ Initiating } & \multirow{3}{*}{$\begin{array}{l}\text { In initiating trust, job provider get list of crowdworker and select one of them to work with. } \\
\text { There are many concerns related to initiating trust, such as crowdwork opportunistic behaviors } \\
\text { (for example crowdworker get monetary reward without properly delivering the solution), } \\
\text { crowdworker can't fulfill job provider's requirement [57,58]. }\end{array}$} & Escrow Services \\
\hline & & Feedback System \\
\hline & & $\begin{array}{l}\text { Accreditation } \\
\text { System }\end{array}$ \\
\hline \multirow[t]{2}{*}{ Augmenting } & \multirow{2}{*}{$\begin{array}{l}\text { In augmenting trust, job provider negotiates with selected crowdworker about deliverables and } \\
\text { prices of contract. The solution must be met with job provider's requirement. The requirements } \\
\text { are often not fixed and unclear. Several job provider said that the result of task that needed } \\
\text { identify requirement usually less predictable and not meet job provider's expectation }[57,58] \text {. }\end{array}$} & $\begin{array}{l}\text { Requirement } \\
\text { Analysis Services }\end{array}$ \\
\hline & & $\begin{array}{l}\text { Contract Formatic } \\
\text { Services }\end{array}$ \\
\hline \multirow[t]{2}{*}{ Main } & \multirow{2}{*}{$\begin{array}{l}\text { In maintaining trust, job provider feel uncertainty about commitment and project status } \\
\text { progress. Young crowdworkers have enthusiasm and creativity, but they ignore } \\
\text { professionalism. Job provider also have concern about crowdworkers commitment (especially } \\
\text { during implementation phase) }[57,58] \text {. }\end{array}$} & $\begin{array}{l}\text { Periodical } \\
\text { Evaluation }\end{array}$ \\
\hline & & $\begin{array}{l}\text { Harmonious } \\
\text { Conflict Resolutio }\end{array}$ \\
\hline \multirow[t]{2}{*}{ User Reputation } & \multirow{2}{*}{$\begin{array}{l}\text { User reputation is asset in social live that plays fundamental role to build online ecosystem, } \\
\text { reputation can be used to increase recommendation in a system. }[59,60]\end{array}$} & Author Reputation \\
\hline & & $\begin{array}{l}\text { Stereotype } \\
\text { Reputation }\end{array}$ \\
\hline \multirow[t]{3}{*}{$\begin{array}{l}\text { Trustworthiness } \\
\text { Estimation }\end{array}$} & \multirow{3}{*}{$\begin{array}{l}\text { Trust estimation is procedure that the trust level for an artifact based on a combination of the } \\
\text { reputation of the user who created the artifact and of the provenance stereotype to which the } \\
\text { artifact belongs. Trust estimation also a procedure that to determines whether artifact is } \\
\text { acceptable based on supplied test entries and background information. This is a form of } \\
\text { probability to make decision ahead }[59,60] \text {. }\end{array}$} & $\begin{array}{ll}\text { Evidence Pric } \\
\text { Performance }\end{array}$ \\
\hline & & $\begin{array}{l}\text { Stereotype } \\
\text { Reputation }\end{array}$ \\
\hline & & User Repu \\
\hline
\end{tabular}

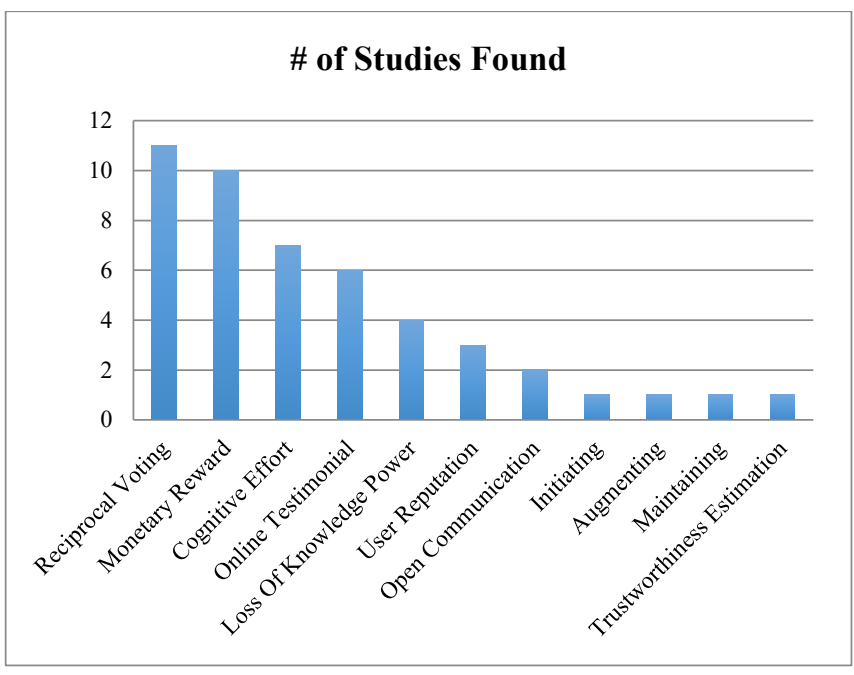

Figure 2: Relationship Between Number of Studies Found and Components Source : Processed by the Author

Figure 2 describes the number of studies found from literature study. The top three most discussed components from the study are Reciprocal Voting, Monetary Reward, and Cognitive Effort.

\section{Implication}

This research has an impact on both academic and practice. Academically, the results of this study can be used as a reference for researchers who are concerned with crowdworking or crowdsourcing. There are 11 components and 38 indicators as result of the research can be used for those who are concern with trust component to develop a crowdwork system model. Practically, the company must pay good attention to these 11 components and 38 indicators, if they want to use crowdwork systems. The crowdwork platform must have a good technology aspect, clean and clear procedure about the system (from initiating, augmenting, and maintaining process), stakeholder voting, and reward procedure about the effort that provided by the crowdworker.

\section{Conclusion \& Future Research}

Trust is critical factor to those who want implement crowdwork system. There are 11 components and 38 indicators of trust in crowdwork system as research result. This research will help the academic and practitioner related to crowdwork system. Stakeholders need to pay attention to these components and 
indicators if they want to use crowdwork system, especially on reciprocal voting, monetary reward, and cognitive effort, since they are the most discussed component from literature study. The platform should allow the job provider and worker to do clean and clear reciprocal voting (more objective assessment) as well as monetary reward procedure. The platform also should provide the features that can minimalize cognitive effort to use the platform. By doing so, the issue of trust stated on introduction (unfair assessment and lack of transparency) can be overcomed.

The resulting components will be processed using quantitative methods (questionnaires) to be used as the basis for making trust system for crowdwork platform.

\section{Conflict of Interest}

The authors declare no conflict of interest during the research process.

\section{Acknowledgment}

This work is supported by Research and Technology Transfer Office, Bina Nusantara University.

\section{References}

[1] A. Kittur, et al., "The Future of Crowd Work. In Proc. CSCW (2013), 130118.

[2] J. Howe "The rise of crowdsourcing. Wired Magazine, 14(6). Available at: http://www.wired.com/wired/archive/14.06/crowds_pr.html. (2006).

[3] U. Huws et al., "Crowd working survey: size of the UK's 'Gig Economy' revealed for the first time. FEPS. Available at: http://www.fepseurope.eu/assets/a82bcd12-fb97-43a6-9346-24242695a183/crowdworking-surveypdf.pdf. (2016c).

[4] U. Huws et al., Crowd working survey: new estimate of the size of Dutch 'Gig Economy'. FEPS. Available at: http://www.fepseurope.eu/assets/778d57d9-4e48-45f0- b8f8-189da359dc2b/crowdworking-survey-netherlands-finalpdf.pdf. (2016a).

[5] U. Huws et al., Crowd working survey: size of Sweden's 'Gig Economy' revealed for the first time. FEPS. Available at: http://www.fepseurope.eu/assets/3f853cec-1358-4fb4-9552-274b55e05ecf/crowd-working surveyswedenpdf.pdf. (2016b).

[6] A. Gawer "Bridging differing perspectives on technological platforms: toward an integrative framework. Research Policy 43(7): 1239-1249. 2014.

[7] D. Ceolin et al., "Combining User Reputation and Provenance Analysis for Trust Assessment. Journal of Data and Information Quality, 7(1-2), 1-28. doi:10.1145/2818382. 2016.

[8] H. Ye, Solvers' participation in crowdsourcing platforms: Examining the impacts of trust, and benefit and cost factors. The Journal of Strategic Information Systems, 26(2), 101-117. 2017. doi:10.1016/j.jsis.2017.02.001.

[9] J. Feller et al., 'Orchestrating' sustainable crowdsourcing: a characterisation of solver brokerages. J. Strateg. Inform. Syst. 21 (3), 216-232. 2012.

[10] D.J. Kim, A study of the multilevel and dynamic nature of trust in ecommerce from a cross-stage perspective. Int. J. Electron. Commer. 19 (1), 11-64. 2014

[11] Porter, Constance \& Donthu, Cultivating Trust and Harvesting Value in Virtual Communities. Management Science. 54. 113-128. 10.1287/mnsc.1070.0765. 2008.

[12] D. Howcroft, Typology of Crowdwork Platforms. Work, Employment and Society, 33(1), 21-38. https://doi.org/10.1177/0950017018760136. 2019.

[13] J. Kücklich, Precarious Playbour: Modders and the Digital Games Industry. Fibreculture Journal. 2005.

[14] Fuchs, Christian. Social Media: A Critical Introduction. London: Sage. ISBN 978-1-4462-5731-9 (pbk), 978-1-4462-5730-2 (hbk). 2014.

[15] S. Tom, What's Yours Is Mine: Against the Sharing Economy. 10.2307/j.ctt1bkm65n. 2016.

[16] S.C. Kuek et al., The global opportunityin online outsourcing, 2015.
[17] K. Cook, Trust and Governance (Braithwaite V. \& Levi M., Eds.). Russell Sage Foundation. 1998. Retrieved July 3, 2020, from www.jstor.org/stable/10.7758/9781610440783

[18] K. Cook, Trust in Society. Russell Sage Foundation. 2001. Retrieved July 3, 2020, from www.jstor.org/stable/10.7758/9781610441322

[19] W. Kristof \& O. Gaby. The Influence of Seller Relationship Orientation and Buyer Relationship Proneness on Trust, Commitment, and Behavioral Loyalty in a Consumer Environment. Journal for the Theory of Social Behaviour. 31 (1). 2012.

[20] D. Tranfield, D. Denyer, P. Smart, Towards a methodology for developing evidence-informed management knowledge by means of systematic review. British journal of management, 14(3), 207-222, 2003.

[21] T. Kohler, Crowdsourcing-Based Business Models: How to Create and Capture Value. California Management Review, 57(4), 63-84. 2015. doi:10.1525/cmr.2015.57.4.63

[22] C. Gerber, "Community Building on Crowdwork Platforms: Autonomy and Control of Online Workers?" Competition \& Change, 2020. doi:10.1177/1024529420914472.

[23] K. Freitas, The Future of Work: New Roles and Capabilities for HR Thanks to Social Media. NHRD Network Journal, 11(2), 35-43. 2018. doi:10.1177/0974173920180209

[24] W. Du, Developing and maintaining clients' trust through institutional mechanisms in online service markets for digital entrepreneurs: A process model. The Journal of Strategic Information Systems. 2018. doi:10.1016/j.jsis.2018.07.001

[25] R. Hofstetter, Should You Really Produce What Consumers Like Online? Empirical Evidence for Reciprocal Voting in Open Innovation Contests. Journal of Product Innovation Management, 35(2), 209-229. 2017. doi:10.1111/jpim.12382

[26] H. Ye et al., Solvers' participation in crowdsourcing platforms: Examining the impacts of trust, and benefit and cost factors. The Journal of Strategic Information Systems, 26(2), 101-117. [2017]. doi:10.1016/j.jsis.2017.02.001

[27] D.G. Rand, Human cooperation. Trends in Cognitive Sciences. 17 (8): $413-$ 25. 2013.

[28] M.A. Nowak, Five rules for the evolution of cooperation. Science. 314 (5805): 1560-63. 2006.

[29] R.M. Axelrod, The evolution of cooperation. New York: Basic Books. 2006.

[30] R.L. Trivers, The evolution of reciprocal altruism. Quarterly Review of Biology. 46 (1): 35-57. 1971

[31] R.A. Clark, Global innovativeness and consumer susceptibility to interpersonal influence. Journal of Marketing Theory and Practice. 14 (4): 275-85. 2006.

[32] D.B. Wooten, Informational influence and the ambiguity of product experience: Order effects on the weighting of evidence. Journal of Consumer Psychology. 7 (1): 79-99. 1998.

[33] R. Cooper, Perspective: The Stage-GateVR idea-to-launch processUpdate, what's new, and NexGen systems. Journal of Product Innovation Management. 25 (3): 213-32. 2008.

[34] R. Sethi et al., Stage-gate controls, learning failure, and adverse effect on novel new products. Journal of Marketing 72 (1): 118-34. 2008.

[35] C. Terwiesch, Innovation contests, open innovation, and multiagent problem solving. Management Science. 54 (9): 1529-43. 2008.

[36] J. Braverman, Testimonials Versus Informational Persuasive Messages. Communication Research, 35(5), 666-694. 2008. doi: $10.1177 / 0093650208321785$

[37] H.B. Brosius, The utility of exemplars in persuasive communications. Communication Research, 21, 48-78. 1994.

[38] P.R. Dickson, The impact of enriching case and statistical information on consumer judgments. Journal of Consumer Research, 8 (4), 398-406. 1982.

[39] E.J. Baesler et al., The temporal effects of story and statistical evidence on belief change. Communication Research, 21 (5), 582-602. 1994.

[40] M.C. Green et al., The role of transportation in the persuasiveness of public narratives. Journal of Personality and Social Psychology, 79, 701-721. 2000.

[41] M.D. Slater, Value-affirmative and value-protective processing of alcohol education messages that include statistical evidence or anecdotes. Communication Research, 23, 210-235. 1996.

[42] J. Howe, Crowdsourcing: why the power of the crowd is driving the future of business. Crown Bus. 2008

[43] N. Kaufman et al., More than fun and money: worker motivation in crowdsourcing- a study on Mechanical Turk. In: Americas Conference on Information Systems, Detroit, Michigan. 2011.

[44] D.C. Brabham, Moving the crowd at iStockphoto: the composition of the crowd and motivations for participation in a crowdsourcing application. First Monday. 13. 2008 
[45] D.C. Brabham, Moving the crowd at Threadless: motivations for participation in a crowdsourcing application. Inform., Commun. Soc. 13 (8), 1122-1145. 2010.

[46] H. Zheng, "Task design, motivation, and participation in crowdsourcing contests. Int. J. Electron. Commer. 15 (1), 57-88. 2011

[47] C. Terwiesch et al., Innovation contests, open innovation, and multiagent problem solving. Manage. Sci. 54 (9), 1529-1543. 2008

[48] L.D. Molm, " Coercive Power in Social Exchange. Cambridge University Press, New York. 1997.

[49] M.M. Wasko, Why should I share? Examining social capital and knowledge contribution in electronic networks of practice. MIS Quart. 29 (1), 35-57. 2005.

[50] G.W. Bock, R.W. Zmud, Behavioral intention formation in knowledge sharing: examining the roles of extrinsic motivators, social psychological forces, and organizational climate. MIS Quart. 29 (1), 87-111. 2005.

[51] Boudreau, K.J., Lakhani, K.R. How to manage outside innovation. MIT Sloan Manage. Rev. 50 (1), 69-76. 2009

[52] M. Boons et al., Feelings of pride and respect as drivers of ongoing member activity on crowdsourcing platforms. J. Manage. Stud. 52 (6), 717-741. 2015.

[53] A. Kankanhalli, Comparing potential and actual innovators: an empirical study of mobile data services innovation. MIS Quart. 39 (3), 667-682. 2015.

[54] R.E. Petty et al., The effects of group diffusion of cognitive effort on attitudes: an information-processing view. J. Pers. Soc. Psychol. 38 (1), 8192.1980 .

[55] E.C. Garbarino, Cognitive effort, affect, and choice. J. Consum. Res. 24 (2), 147-158. 1997.

[56] A. Afuah, C. Tucci, Crowdsourcing as a solution to distant search. Acad. Manage. Rev. 37 (3), 355-375. 2012.

[57] H.Ye, A. Kankanhalli, Investigating the antecedents of organizational task crowdsourcing. Inform. Manage. 52 (1), 98-110. 2015

[58] A. Kankanhalli et al., Contributing knowledge to electronic knowledge repositories: an empirical investigation. MIS Quart. 29 (1),113-143. 2005.

[59] T. Krishnaprasad, P. Anantharam, C. A. Henson, and A. P. Sheth. Comparative trust management with applications: Bayesian approaches emphasis. Future Generation Computer Systems. 31. 182-199. 2014.

[60] J. Gao, Zhou, T. Evaluating user reputation in online rating systems via an iterative group-based ranking method. Physica A: Statistical Mechanics and Its Applications, 473, 546-560. doi:10.1016/j.physa.2017.01.055. 2017. 